\title{
A Study On The Convergence Core Competencies Influencing The Team Creativity Of Industrial Workers
}

\author{
EunJoo Kim ${ }^{1}$ \\ ${ }^{1}$ Eulji University, Geonggido, South Korea
}

Article History: Received:11 January 2021; Accepted: 27 February 2021; Published online: 5 April 2021

\begin{abstract}
The purpose of this study is to analyze the effect of core competencies of industrial workers on team creativity in order to establish the direction of core competency education of universities as the 4th industrial revolution era arrives. For this purpose, 104 industrial workers were studied to investigate the impact of convergence core capacity on team creativity. The effect of convergence core competency of industrial workers on team creativity was analyzed. The analysis results show that creative thinking and consideration affect team creativity as well as industrial workers' convergence core capabilities.
\end{abstract}

Keywords: Convergence Core competencies, Team Creativity, Industrial workers

\section{Introduction}

The recognition that it is important to cultivate creative talents in terms of industry competitiveness has already started in the United States, while Korea also attempted to systematically develop a convergent talent education research program in 2011[1]. In order to adapt to new technological change in the country, a priority is to cultivate talented people who have core competencies in convergence. In particular, as a part of innovation in industry, abandoning the seniority-based personnel system and applying the concept of competency to new personnel management is key. In addition, interview questions based on the competency models of companies such as Apple and Google are increasingly being used to test creativity. According to surveys of domestic companies, $82 \%$ of the top 100 companies were building competency models by the year 2005 , and $77 \%$ of them conduct competency evaluations [2].

Core competencies can better predict job performance than intelligence. These variables should be measured rather than intelligence because they are not affected by socio-economic factors such as race, sex, and economic power. However, a point of caution here is that creativity among different competencies varies according to gender, according to in a study by Kay and Koval (2015) [3], who reported that men are more creative than women. These results are intended only for Americans and may be based on certain cultural interpretations. As such, competency represents a variety of research results, depending on social and cultural aspects. Competency is used as a criterion for companies to place employees in the right positions and to evaluate performance. In other words, convergence core competence represents an important independent variable used to derive high organizational performance. In addition, the emergence of the terms participation, sharing, and collaboration within an organization shows that importance is placed on the performance of the individual as well as the performance of the team.

One of the major changes in the organization of modern society is the expansion of team work. Modern organizations have reorganized existing departments to perform tasks efficiently and increase synergy among members. For example, more than $80 \%$ of Korean companies have already reported the adoption of team-based organization [4]. In the context of teamwork, team adaptations through the interaction with team members includes concepts that are different from individual adaptations. In other words, at the team level, communication between the members is conducted through the network and tasks also change interdependently. Therefore, new changes such as employing a team structure as well as ability and goal-oriented behavior and cognition can be explained by creative innovation in team adaptation [5].

A study by Juil Lee et al. (2019) found that employee creativity was an important factor in human resource management for industrial workers [6]. A study by Jingli Li (2018) showed that each team member's ability- as well as the ability to exchange information among team members, affect team creativity [7]. In this context, this study is meaningful in that it analyzed the impact of convergence core competencies on team creativity, focusing on industry workers, in order to ensure the continued growth of convergence core competencies among

Article Info:

(To be filled up by the publisher) 
college and university students following the advent of the Fourth Industrial Revolution. Without the continued growth of convergence core competency among students, the team creativity of industrial workers cannot be guaranteed. Also, industry sustainability cannot be expected. Therefore, the growth of the convergence core competencies of students can lead to the enhancement of the convergence core capacity of industrial enterprises. As a result, we can expect sustainability and economic development as a product of the promotion of team creativity in industries. Therefore, in this study, it is important to minimize the mismatch between university education and industry demands and prepare basic data on interconnected education between universities and industries in order to foster talented people with the convergence core capabilities necessary for the sustainability of future society. The following are specific research questions we asked to achieve these research objectives.First, what are the core competencies and team creativity of industrial workers?

Second, what is the relationship between the convergence core competency of industry workers and team creativity?

Third, what is the impact of core competencies of industrial workers on team creativity?

\section{Literature Reviews}

\subsection{Convergence core competencies}

The reasons for the expansion of convergence education in Korea include strengthening human resource competitiveness in order to maintain and expand global political and economic leadership in accordance with the international status of Korea. Furthermore, it is recognized that the quality of university education is more important than anything else in order to secure the competitiveness of Korean companies and the competitiveness of developments in science and technology. Reliance on convergence education has increased as a practical alternative to secure future national competitiveness. In addition, from the viewpoint of becoming the foundation of "creative industries," convergence education is becoming more and more an education that leads a new era rather than merely cultivating humanity. Therefore, the government has proposed a policy to cultivate creative and convergent human resources that will lead to future science and technology development, which is an asset of national competitiveness [8].

The convergence core competencies vary as the definitions of convergence vary. The definition of convergence core competencies is often based on the needs and objectives of industry rather than an academic approach. In the study of the Samsung Advanced Institute of Technology [9], we defined convergence talents as $\pi$-shaped talents, for example, individuals who have expert knowledge in two or more fields and have acquired competence to interconnect. Chul-soo, Ahn (2010) described the talented individuals needed for the future, termed as A-type talent, as those who have common sense and tolerance for other fields as well as expert knowledge in one field [10].

Yoo Eun-jung (2009) classified factors of core competence into five competencies: common consensus competence, consensus on humanities, consensus on the social field, consensus on natural discipline, and consensus on arts. Moreover, it is essential that various knowledge, skills, and attitudes are integrated within each competency [11]. Baek Yoon-soo(2011) expressed elements of convergence core competencies in 4C and presented them as four factors: convergence knowledge and conceptual formation, creativity, communication, and care for others [12]. As illustrated by the example above, factors of convergence core competencies are being discussed in a variety of conceptual dimensions.

The convergence core competency described in this study is not a new concept. Rather, it is a concept of core competency for converged human resources education developed by Park Ki-moon (2014) [13]. Park Ki-moon (2014) defineds convergence core competency as a concept composed of problem-solving skills, communication skills, cooperation, use of convergence tools, consideration and responsibility, with elements of creative thinking, critical thinking and knowledge [13].

\subsection{Team Creativity}

Team creativity is the ability of individuals to potentially converge, especially with creativity, to interact with each member to come up with ideas for problem resolution and ultimately solve problems creatively [14]. The study of team creativity has mostly been discussed considering the individual level, not the team level, as the basis of creative expression. Emotional intelligence scholar Daniel Goleman stated that for team creativity an autonomous control of his work and ideas, resources to complete his work, and ample time to create are required [15]. The study of team creativity began in earnest with the study of the organizational innovation and 
the creativity education model of Amabile (1988) [16]. In other words, there is a need for research on the relationship between the core competencies of team members and team creativity as well as their influences.

From high-tech companies like Apple Computer to manufacturers like 3M, there are a variety of problems that cannot be solved by the effort of one person or one sector. To solve these problems effectively, team creativity among multiple people with convergence capabilities can be the basis for problem solving [17]. Often, our society is concerned with the ability of one person but with team creativity it is possible to derive creative ideas through collaboration and convergence among individuals and teams $[18,19]$.

In the age of the Fourth Industrial Revolution, future education emphasizes core competencies. In particular, the future society demands creative talents that combine core competencies to fuse, apply, and utilize knowledge to solve various problems. Professor Gary Hamel of London Business School emphasizeds that creative talents that work together and collaborate with people from different disciplines and diverse fields are important components of team creativity [20].

In particular, facilitating talented people who foster creative convergence skills is also an important task for university education as competition among countries intensifies and uncertainties about the future increase[21]. Creativity is also the factor in highest demand across business and industry [22, 23]. In this context, research has been carried out in various aspects, including the revision of curricula, teaching learning strategies, and teacher training in relation to creative competences $[24,25,26]$. Therefore, those who cultivate creativity and convergence capabilities need to focus on a methodical search through education in accordance with the needs of the times and society. Such efforts and demands are being emphasized not only in the education sector, but also in attempts to maximize corporate profits. In particular, many organizations have been reorganized into a team-based format, breaking away from the hierarchical structure of individual capabilities. As a result of such a reshuffle, many companies have generated profits and achieved corporate development. With this development, these companies emphasize communality and team creativity to generate ideas and solve team problems, placing an increased importance on the collective effort of the organization members [27].

To study the factors affecting team creativity, we looked at the effectiveness of team members' efforts, goaloriented behaviors, cognition, etc. Studies by Kozlowski and Klein (2000) showed that the factors affecting team creativity stem from the perception, influence, behavior, and characteristics of the individual members [28]. Woodman, Sawyer, and Griffin (1993) found that team members' problem-solving strategies and team members' cohesion affect team creativity [29]. It has also been shown that more so than traditional thinking, converged thinking finds creative alternatives without fear of the process of nonlinear thinking [30]. These converged thinking factors lead the team to engage in thought activities that embrace different levels of knowledge and information. As such, team creativity has been researched based on various views and perspectives on members of the group. However, research based on the convergence core competency factors of team members and how these factors affect team creativity is still insufficient. Therefore, it is necessary to study which factors in the convergence core competences of the members can generate the creative performance of the team.

\section{Research Methodology}

\subsection{Subject}

The purpose of this study is to investigate the effect of core competencies of industrial workers on team creativity. The study distributed questionnaires to industrial workers in the Seoul metropolitan area for two weeks from September 4 to 28, 2018, and analyzed the remaining 104 respondents, excluding those with missing answers.Table 1 shows the generalities of the study subjects.

Table 1.Demographic information $(\mathrm{N}=104)$

\begin{tabular}{llll}
\multicolumn{2}{c}{ Observation variable } & Frequency (persons) & Percent $(\%)$ \\
\cline { 2 - 4 } Gender & Male & 57 & 54.8 \\
\cline { 2 - 4 } & Female & 47 & 45.2 \\
\hline \multirow{2}{*}{ Age } & $20 \sim 30$ & 20 & 19.2 \\
\hline
\end{tabular}




\begin{tabular}{|c|c|c|c|}
\hline & $31 \sim 40$ & 26 & 25.0 \\
\hline & $41 \sim 50$ & 30 & 28.8 \\
\hline & $51 \sim 60$ & 22 & 21.2 \\
\hline & More than 60 years & 6 & 5.8 \\
\hline \multirow{5}{*}{ Career } & Less than 5 years & 29 & 27.9 \\
\hline & $5 \sim 10$ years & 23 & 22.1 \\
\hline & 11 20 years & 27 & 26.0 \\
\hline & $21 \sim 30$ years & 19 & 18.3 \\
\hline & More than 31 years & 6 & 5.8 \\
\hline \multirow{5}{*}{ Education } & High school graduation & 1 & 1.0 \\
\hline & College graduation & 10 & 9.6 \\
\hline & University graduation & 49 & 47.1 \\
\hline & Master & 24 & 23.1 \\
\hline & Doctor & 20 & 19.2 \\
\hline \multirow{5}{*}{ Work scale } & Less than 10 & 40 & 38.5 \\
\hline & $10 \sim 100$ & 38 & 36.5 \\
\hline & $100 \sim 300$ & 8 & 7.7 \\
\hline & $300 \sim 500$ & 6 & 5.8 \\
\hline & More than 500 & 12 & 11.5 \\
\hline \multirow{5}{*}{ Job field } & Service position & 17 & 16.3 \\
\hline & Management, office workers & 41 & 39.4 \\
\hline & a business position & 14 & 13.5 \\
\hline & a professional job & 27 & 26.0 \\
\hline & Other & 5 & 4.8 \\
\hline
\end{tabular}

Among the general characteristics of the subjects, In the case of sex, 57(54.8\%) were male and 47(45.2\%) were female. The age distribution was the largest among those aged 41 to 50, with 30(28.8\%). Career was less than 5 years, and education was the highest University graduation with $49(47.1 \%)$. The work scale was the largest with 40(38.5\%), and job field distribution had the highest management, office workers with 41(39.4\%).

\subsection{Measuring instrument}

This study is to identify the convergence core competences that affect team creativity of industrial workers. The composition of the questionnaire consists of 6 questions asking demographic characteristics, 9 questions asking the current level of the convergence core capability, 24 questions asking the level of team creativity, and a total of 39 questions. 
Table 2.Question composition

\begin{tabular}{cccc}
\hline & division & $\begin{array}{c}\text { Number of } \\
\text { questions }\end{array}$ & Cronbach' $\alpha$ \\
\hline $\begin{array}{c}\text { Demographic } \\
\text { information }\end{array}$ & $\begin{array}{c}\text { Gender, age, career, educational, } \\
\text { work scale, job field }\end{array}$ & 6 & - \\
\hline $\begin{array}{c}\text { Creative thinking, critical thinking, } \\
\text { converged knowledge, problem } \\
\text { core competencies }\end{array}$ & $\begin{array}{c}\text { solving, communication, cooperation, } \\
\text { use of convergence tools, } \\
\text { consideration, responsibility }\end{array}$ & 9 & .903 \\
\hline Team creativity & $\begin{array}{c}\text { Diversity (4), Leadership (8), } \\
\text { Derivation of Idea (7), Autonomy (5) }\end{array}$ & 24 & .911 \\
\hline
\end{tabular}

The convergence core competency framework developed by Park Ki-moon (2014) was used for the analysis [13]. The core capabilities of convergence human resources are divided into converged cognitive capabilities (creative thinking, critical thinking, and converged knowledge), converged performance capabilities (using problem-solving, communication, cooperation, and convergence tooling), and converged attitude capabilities (attention, responsibility). The Cronbach' alpha value was calculated to ensure the reliability of the measuring tool. The reliability Cronbach' $\alpha$ value of the question asking the current level of convergence core capacity was .903. For each subclause, the Likert 5-point scale was used with 1 point 'very low', 2 point 'low', 3 point 'ordinary', 4 point 'high' and 5 point 'very high'. Team creativity was used to correct and supplement the questions used in the study by Choi Jong-in and Kim Hak-soo (2015) for the purpose of this study [31]. Team creativity was divided into four sub-dimensiones: idea elicitation, diversity, leadership and autonomy, and consisted of seven, four, eight, and five questions, respectively, measured on a five-point scale of the recertion. The reliability of the item asking team creativity was 0.911 . The variables of each subcontent were used as Likert 5 point scale with 1 point of 'very low', 2 points of 'low', 3 points of 'normal', 4 points of 'high' and 5 points of 'very high'.

\subsection{Data analysis}

To analyze the problems of this study, the collected data were analyzed using the PASW Statistics 18.0 program. Cronbach's alpha coefficients were calculated to determine the internal consistency of the survey instruments. The minimum value, maximum value, average, and standard deviation were calculated to analyze the core competence and team creativity level of industrial workers. Pearson correlation analysis was conducted to explore the relationship between convergence core competence and team creativity. Finally, a multiple regression analysis was conducted to analyze the effects of the core competencies of industrial workers on team creativity.

\section{Result}

\subsection{Convergence core competencies of industrial workers and team creativity level}

Table 3.Convergence core competencies and team creativity technical statistics $(\mathrm{N}=104)$

\begin{tabular}{ccccc} 
& \multicolumn{2}{c}{ classification of questions } & M & SD \\
\hline \multirow{3}{*}{$\begin{array}{c}\text { Convergence core } \\
\text { competencies }\end{array}$} & $\begin{array}{c}\text { Convergence recognitior } \\
\text { competencies }\end{array}$ & creative thinking & 3.34 & .915 \\
\cline { 2 - 5 } & & critical thinking & 3.29 & .977 \\
\cline { 2 - 5 } & Convergence & Converged Knowledge Understanding & 3.08 & .949 \\
\hline
\end{tabular}


EunJoo Kim ${ }^{1}$

\begin{tabular}{cccc}
\hline \multirow{2}{*}{$\begin{array}{c}\text { performance } \\
\text { competencies }\end{array}$} & Communication & 3.56 & 1.148 \\
\cline { 2 - 4 } & Collaboration & 2.94 & 1.240 \\
\cline { 2 - 4 } & Use convergence tools & 3.68 & 1.065 \\
\cline { 2 - 4 } $\begin{array}{c}\text { Convergence attitude } \\
\text { ability }\end{array}$ & consideration & 3.86 & .875 \\
\cline { 2 - 4 } & responsibility & 3.55 & 1.029 \\
\cline { 2 - 4 } Team Creativity & Diversity & 3.38 & .932 \\
\cline { 2 - 4 } & Leadership & 3.58 & .881 \\
\cline { 2 - 4 } & elicitation of ideas & 3.41 & .837 \\
\cline { 2 - 4 } & Autonomy & 3.57 & .924 \\
\hline
\end{tabular}

Among the convergence core competencies of industrial workers, M(SD) of "creative thinking," a sub-factor of convergence cognitive ability, was 3.34(.915), $\mathrm{M}(\mathrm{SD})$ of " problem solving," a sub-factor of convergence performance, 4.17(.667), and $\mathrm{M}(\mathrm{SD})$, a sub-component of convergence competencies, were 3.86.875). Among them, "problem solving" was the highest. The level of team creativity was also the highest at 3.58 (.881) for 'leadership' and the lowest at $3.41(.837)$ for 'elicitation of ideas'.

\subsection{The relationship between convergence core competencies and team creativity of industrial workers}

Pearson correlation was conducted to explore the relevance of convergence core competencies of industry workers to team creativity. The analysis results are shown in Table 4.

Table 4.Correlation analysis between converged core competencies and team creativity $(\mathrm{N}=104)$

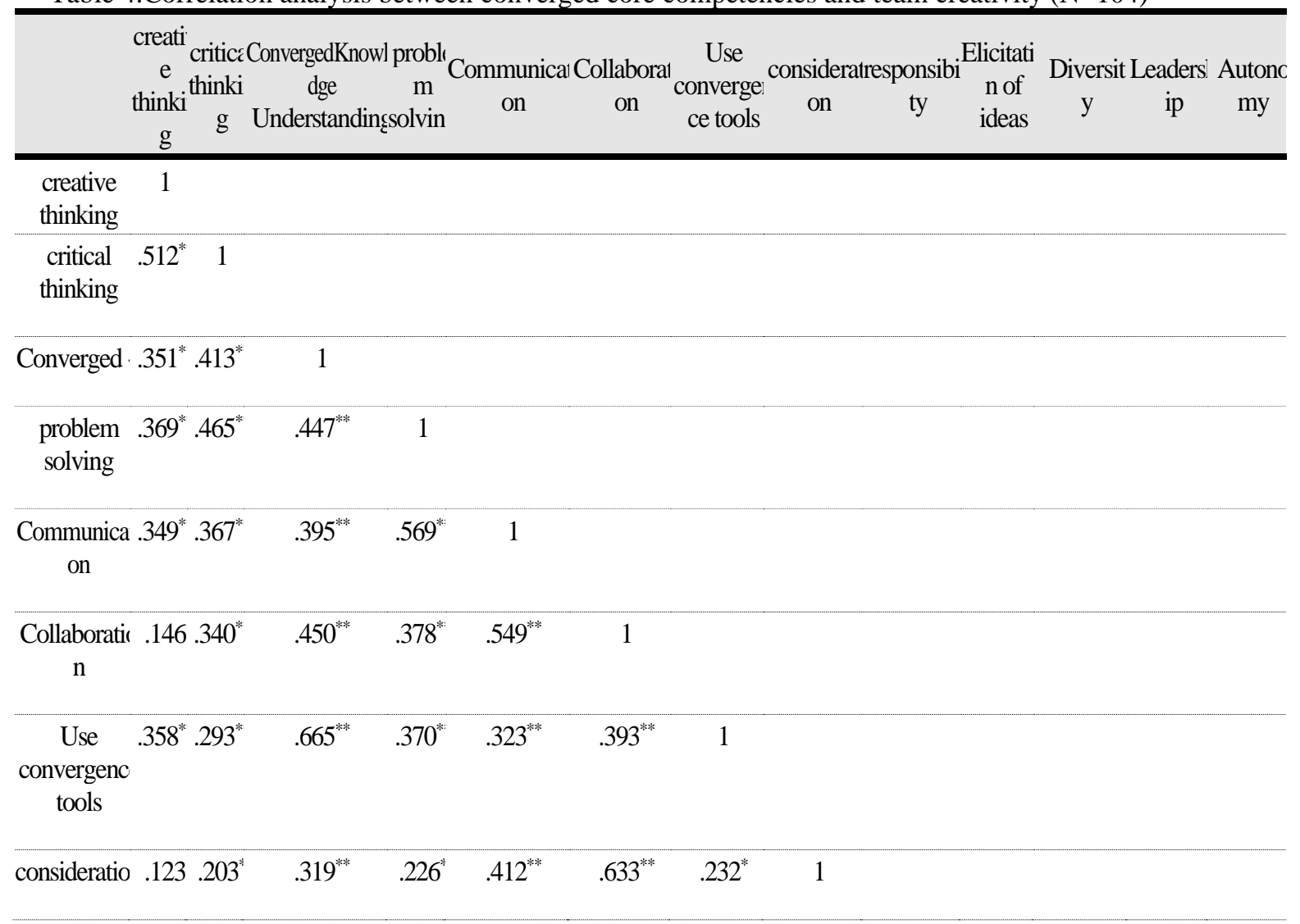


A Study On The Convergence Core Competencies Influencing The Team Creativity Of Industrial Workers

\begin{tabular}{|c|c|c|c|c|c|c|c|c|c|c|c|}
\hline responsibilit $.376^{*} .362^{*}$ & $.347^{* *}$ & $.388^{* *}$ & $.393^{* *}$ & $.524^{* *}$ & $.361^{* *}$ & $.566^{* *}$ & 1 & & & & \\
\hline $\begin{array}{l}\text { Elicitation c } .468^{*} .265^{*} \\
\quad \text { ideas }\end{array}$ & .190 & $.260^{*}$ & $.293^{* *}$ & $.308^{* *}$ & $.261^{* *}$ & $.343^{* *}$ & $.450^{* *}$ & 1 & & & \\
\hline Diversity $.235^{\sharp} .175$ & .165 & .068 & -.033 & .053 & .122 & .100 & .118 & $.456^{* *}$ & 1 & & \\
\hline Leadership .310* .063 & .162 & .177 & .166 & $.210^{*}$ & $.206^{*}$ & .157 & .152 & $.609^{* * *}$ & $.370^{* *}$ & 1 & \\
\hline Autonomy $.316^{*} .218^{*}$ & $.237^{*}$ & .146 & $.291^{* *}$ & .166 & $.254^{* *}$ & .145 & .150 & $.515^{* *}$ & $.411^{* *}$ & $.609^{* *}$ & 1 \\
\hline
\end{tabular}

$* * * p<.001$

The correlation between convergence core competencies and team creativity resulted in significant correlation between all the variables $(\mathrm{p}<.001)$, all of the lower factors of convergence core competency, showed static correlation with team creativity. Also, the highest static correlations was shown to creative thinking and elicitation of ideas $(\mathrm{r}=.468, \mathrm{p}<.001)$, and these results can be predicted to be the ability to think creatively, the convergence core competencies that represents the highest correlation with team creativity.

Table 5.Regression analysis of converged core competencies on team creativity ( $\mathrm{N}=104)$

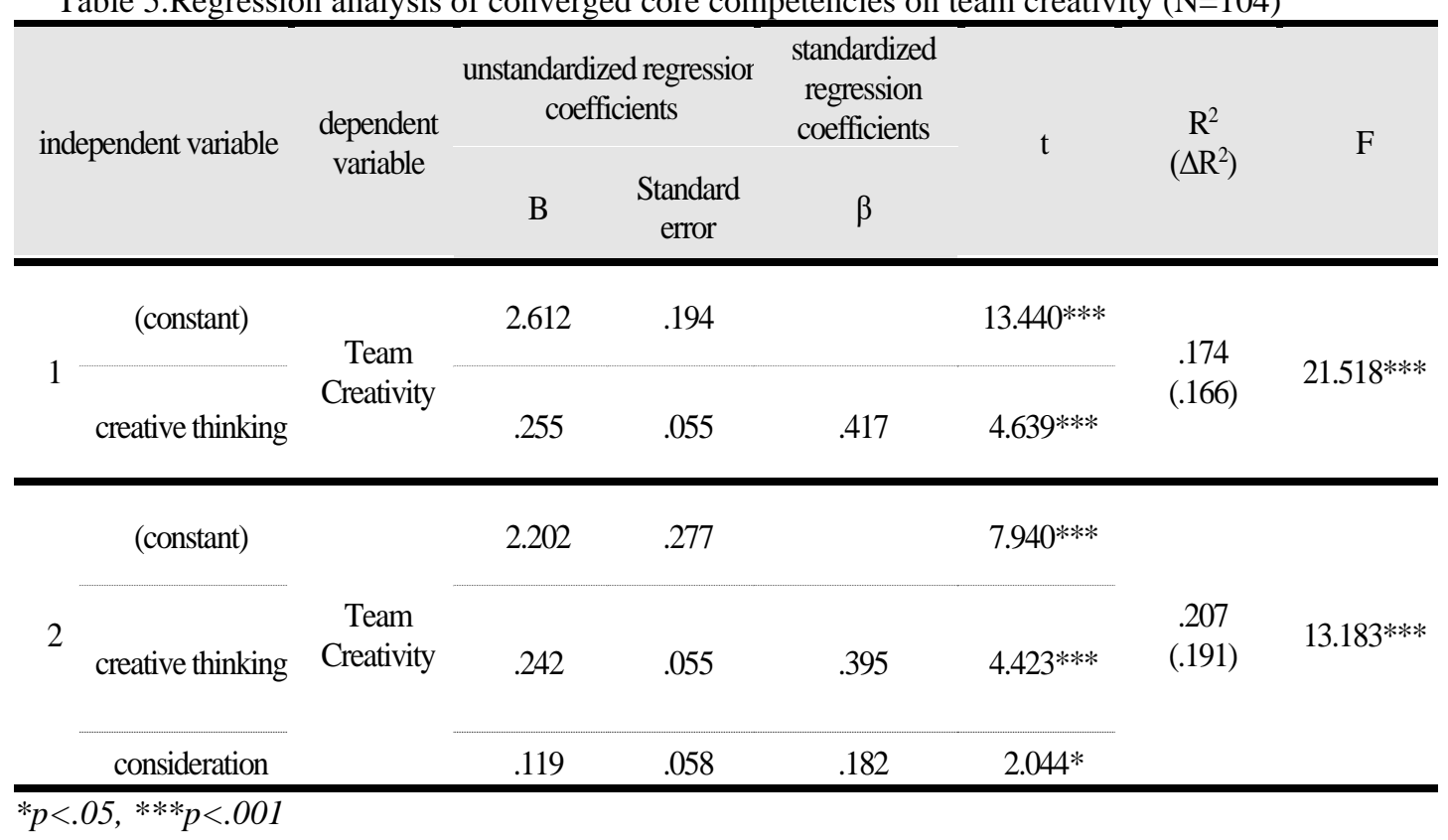

The validation of Model 1 analyzed that the creative thinking set as a control variable was statistically significant $(\mathrm{F}=.174, \mathrm{p}<.001)$. The modified $\mathrm{R}^{2}=.166$, the independent variable, Creative Thinking, was analyzed to describe team creativity by $16.6 \%$. In addition, creative thinking has a statistically significant positive effect on team creativity $(\beta=.417, \mathrm{p}<.001)$.

The verification results of Model 2 showed an increase of $2.5 \%\left(\Delta \mathrm{R}^{2}=.025\right)$ to the revised $\mathrm{R}^{2}=.191$, and an increase in creative thinking $(\beta=.395, \mathrm{p}<.001)$ and caring $(\beta=.182, \mathrm{p}<.001)$ among the subcomponents of converged core competencies and. It was analyzed that $182, \mathrm{p}<.001)$, had a statistically significant positive effect on team creativity. The control variable, Creative Thinking, was shown to have a statistically significant effect on team creativity in Model 1, and also a statistically significant effect on Model 2. Also, when compared with the standardized beta value $(\beta)$, the effect on creativity of the team was higher in the order of creative thinking and consideration. Beta means that team creativity changes in the same direction and size when the core competencies of creative thinking and consideration increase. The regression formula derived from these 
results is as follows.

\section{Team creativity $=2.202+.242($ creative thinking $)+.119($ consideration $)$}

According to the derived regression formula, if creative thinking and consideration are zero, the average of team creativity is 2.202 , and if creative thinking increases by one point, the average of team creativity will increase by 0.242 points, and if caring increases by one point, the average of team creativity will increase by 1.119 points.

\section{Conclusion and Discussion}

\subsection{Conclusion}

This study addresses the sustainability of society as a whole by promoting the team creativity of industrial workers. In particular, it can be used as a basic model to drive the sustainability of the social economy as an empirical study confirming the impact of convergence core competencies on team creativity in the era of the Fourth Industrial Revolution. In addition, depending on the occupational groups of the industry workers studied in this study, the core competencies required for them may vary. Nevertheless, this study is meaningful as an empirical study to present the model of convergence core competencies as a common requirement among industrial workers.

In conclusion, we analyzed the effect of industrial worker's core competence on team creativity output based on a review of several previously published studies. Creative thinking and the consideration of core competence of team members were found to influence team creativity. Kwon et al. (2018) conducted a survey of senior managers of Korean shipyards with an emphasis on communication competence based on the consideration of the characteristics of team members for organizational management and success [32]. Like Leonardo da Vinci, the time has come for a genius to do everything. In order to live in an era where experts from various fields work together to accomplish one big task, it is important to recognize that team creativity is more important for individual college students than individual creativity. Thus, it is necessary to emphasize creativity at the team and group level. This necessity for education should be extended to society as a whole.

\subsection{Discussion}

Facing of an era when the Fourth Industrial Revolution is becoming a reality and interest in future education methods to prepare for it are increasing around the world, traditional instructor-style teaching methods have limitations in promoting learners' continued team creativity. Therefore, many educators have recognized that there is a limit to fostering talented people who can demonstrate team creativity through existing education methods, and there is a growing awareness that new educational attempts and applications are urgently needed [33]. In particular, Root-Bernstein, an art historian, developed a variety of methods for observing, shaping, abstraction, pattern recognition, pattern formation, analogy, body thinking, empathy, dimensional thinking, and modeling; in total 13. ideas were proposed [34]. As a result of this change, research on teaching methods that can induce creative ideas for students has been initiated in Korea, instead of teaching one-sided content. The design of various group activities such as discussion methods and cooperative learning that involves listen to the opinions of other people has been undertaken, with the aim of demonstrating team creativity by internalizing the consideration of all members in the team.

In addition, entrepreneurship education is offered as a core educational method to cultivate the ability to develop innovative technologies based on creative thinking and to cultivate talented individuals with continuous adaptability as team members [35]. If general education is based on learning, then entrepreneurship education is empirical learning based on the idea of an individual or a team. In other words, entrepreneurship education places a greater emphasis on vision and creativity. This approach may help students to develop strategies to run themselves, as well as developing entrepreneurship and creativity among the whole team.

Project learning is a form of learning in which learners explore and collaboratively solve issues by solving complex, unstructured, and realistic problems. Team project-based learning is used in many college classes because its educational effectiveness is acknowledged in terms of utilizing and creating knowledge through tasks based on real-world context. In particular, creative knowledge through collaboration with team members enables learners to learn and perform at a higher level [36, 37]. As such, universities, which are institutions in 
charge of future education that at the same time foster high-quality manpower for future society, should strive to continuously promote team creativity through various educational methods.

Many researches have expressed great interest in creativity in various aspects of companies and schools. However the subject is mostly focused on the individual dimension. The results of this study suggest the necessity of research on team creativity in addition to the general interest in teams. In order to effectively manage a team project type education in a higher education context, it is necessary to support the program that can improve the teaching proficiency of the instructor. Also, educational content centered on the convergence ability that can actually enhance team creativity in the classroom is required. Finally, further research on the methodology should be actively carried out in the future.

Despite the theoretical and empirical significance of this study, this study also had some limitations. First, in selecting samples, it is difficult to list industry workers in various fields. A large number of samples can be obtained by selecting a single large company in the course of the study. However, this could not be obtained in the present study because the review sampled people working for various industries. Therefore, further studies will need to be conducted on workers in more diverse industries and organizations. Second, this study investigates what factors among the core competencies of industrial workers affect team creativity, and neglecteds the fact that the types and characteristics of teams can act as interference factors. Therefore, further research should be done on the general characteristics of the types and characteristics of the team, not individual workers.

\section{References}

1. Sim, J. H., Lee, Y. R., and Kim, H. K. Understanding STEM, STEAM Education, and Addressing the Issues Facing STEAM in the Korean Context. Journal of the Korean Association for Research in Science Education, 2013, 35(4), 709-723.

2. Swetha Kodali \& A. Mrunalini, "Occupational Health Problems among Workers in Concrete Based Manufacturing Industry - A Review of Research", International Journal of Educational Science and Research (IJESR), Vol. 8, Issue 4, pp , 39-44

3. Lee, M. H. Prerequisite for success of technology commercialization, Digital Times, 2014.06.24. http://m.dt.co.kr/contents.html?article_no=2014062502012251796002.

4. C. Ranjith, C. Hemamalini \& K. Senthil Kumar, "An Analysis of the Health Hazards of Workers in Transport Industry", International Journal of Business Management \& Research (IJBMR), Vol. 7, Issue 2, pp, 9-16

5. Kay, A. C., \&Koval, C. Z. A gender bias in the attribution of creativity: Archival and experimental evidence for the perceived association between masculinity and creative thinking. Psychological Science, 2015, 26(11), 1751-1761.

6. K. M. Ayshath Zaheera, C. B. Senthilkumar \& S. Nallusamy, "Investigation Study on Effective Tools for Conscription of Various Industrial Applications", International Journal of Mechanical and Production Engineering Research and Development (IJMPERD), Vol. 8, Issue 1, pp, 1221-1230

7. Korea Employers Federation. Capacity-Based Employment Interview Technique and Evaluation SKILL UP. Seoul: Korea Employers Federation, 2012.

8. Rashmi Kumar, "Indian Jute Industry has a Sustainable Future", International Journal of Business and General Management (IJBGM), Vol. 6, Issue 4, Jun - Jul 2017; 21-32

9. Burke, C. S., Stagl, K. C., Salas, E., Pierce, L., and Kendall, D. Understanding team adaptation: a conceptual analysis and model. Journal of Applied Psychology, 2006, 91(6), 1189.

10. Isaac Zeb-Obipi, "Frameworks of Industrial Relations Analysis: A Re-Visit to Industrial Relations Theory", International Journal of Human Resources Management (IJHRM), Vol. 7, Issue 1, pp; 1-12

11. Juil Lee, Sangsoon Kim, Jiman Lee and Sungok Moon. Enhancing Employee Creativity for A Sustainable Competitive Advantage through Perceived Human Resource Management Practices and Trust in Management. Sustainability, 2019, 1-16. 
12. Kanchana Vinoth \& S. Vasantha, "Impact of Employer Brandon Employee Satisfaction, with Special Reference to IT Industry", BEST: International Journal of Management, Information Technology and Engineering (BEST: IJMITE); Vol. 3, Issue 9, pp, 53-60

13. Jingli Li, Min Zhao, Guanjun Xia and Chao Liu. The Relationship between Team Hometown Diversity and Team Creativity: From the Chinese Perspective. Sustainability, 2018, 1-15.

14. Ministry of Education, Science and Technology. Future of Korea with talented people and advanced science and technology. 2012 business report. Ministry of Education, Science and Technology . 2010

15. Son, W. Human resources required for business. January issue of physics and high technology. 2004.

16. Ahn, C. S. T-shaped talent Jump over A-shaped talent. Monthly Innovation Leader March 2010.

17. Yoo, E. J. Interdisciplinary fusion. 2009 Korea Industrial Technology Association Forum June 15, 2009.

18. Baek, Y. S., Park, H. J., Kim, Y. M., Noh, S. G., Park, J. Y., and Lee, J. Y., Direction of Korean STEAM Education. Journal of Learner-Centered Curriculum and Instruction, 2011, 1(4), 149-171.

19. Park, K. M. Development of Key Competency Factors for Measuring Study Outcomes in Science, Technology, Engineering, Arts, Mathematics(STEAM). Korean technology education association, 2014,14(2), 234-257.

20. Kim, J. H. A study on the effect of team composition and team characteristic on team creativity. A master's thesis, University of Hoseo, 2010.

21. Goleman, D. Leadership That Gets Results. Harvard Business Review, 2000, 78(2), 78-90.

22. Amabile, T. M. A model of creativity and innovation in organizations. Research in organizational behavior, 1988, 10, 123-167.

23. Martin, R. L. The design of business : why design thinking is the next competitive advantage, Harvard business press, 2009.

24. Brown, T. Change by design : how design thinking transforms organizations and inspires innovation, Harper Collins Publishers, 2009.

25. Shalley. C., Zhou, J., \& Oldham, R. G. The effects of personal and contextual characteristics on creativity: Where should we go from here. Journal of Management, 2004,30(6), 933-958.

26. Chosun Biz, 2015, "[Try! 2015] "Strategic Competence Enhancement" This year will be a year for businesses", January 30, 2015.

27. Korea Educational Development Institute. Future Vision of Korean Education. Seoul: Harkjisa, 2011.

28. Giovanni Schiuma. Arts catalyst of creative organisations for the fourth industrial revolution. $J$. Open Innov. Technol. Mark. Complex. 2017, 3(4), 20; https://doi.org/10.1186/s40852-017-0072-1 (registering DOI)

29. Sogol Homayoun, \&Danah Henriksen. Creativity in Business Education: A Review of Creative SelfBelief Theories and Arts-Based Methods. J. Open Innov. Technol. Mark. Complex.2018,4(4), 55; https://doi.org/10.3390/joitmc4040055

30. Kang, E. C., \& Kim, S. Y. An Analogy-using Instructional Design for facilitating Science Creativity. The Journal of Education Research, 2002, 23(2), 1-22.

31. Kang, H. K., \& Choi, S. Y. Elementary School Science Instructional Methods for Nurturing Creativity. Journal of science and science education, 2002, 14, 1-16.

32. Seo, H. A., Song, B. H., Kwon, D. K., Yoon, K. S., \& Kim, S. N. Development and implementation of cyber in service program of science teachers for creativity in science education. The journal of Korean teacher education, 2004, 21 (3), 305-328. 
33. Shally, C. E., Gilson, L. L., \& Blum, T. C. Interactive effects of growth need strength, work context, and job complexity on self-reported creative performance. Academy of management journal, 2009, 52, 489-505.

34. Kozlowski, S. W. J., and Klein, K. J. A multilevel approach to theory and research in organizations: Contextual, temporal, and emergent processes. In K. J. Klein and S. W. J. 2000.

35. Woodman, R. W., Sawyer, J. E., and Griffin, R. W. Toward a theory of organizational creativity. Academy of Management Review, 1993, 18: 293-321.

36. Trefinger, D. J., Isaksen, S. G., \& Dorval, K. B. Creative problem solving: An introduction(4th ed.) Waco, TX: Prufrock Press. 2006.

37. Choi, J. I., Kim, H. S. A study of the taking curvilinear approach between ethical leadership and innovative performance: Focused on the moderating effect of team duration. Korean academy of organization and management, 2015, 39(4), 55-88.

38. Kwon, A. M., Park, H., Hahn, H., Lee, I. Y., \& Kwon, T. H. Motivators of MBWA and Communicational Factors behind Them: A Case Study on a Korean Shipyard. J. Open Innov. Technol. Mark. Complex.2018, 4(3), 29; https://doi.org/10.3390/joitmc4030029

39. Korea Education and Research Information Service. A Study on the Effectiveness of SW Education School in 2015 (Research Report RR 2015-6). Daegu Metropolitan City: Korea Education and Research Information Service. 2015.

40. Jeon M. K. Suggestion of composition of art and idea tool based on artist's idea. Gyeongin National University of Education. Master Thesis. 2018.

41. Chung, C. G. Current Status and Tasks of University Entrepreneurship Education for Young Entrepreneurship Activation. The HRD review, 2013, 40-59.

42. Whang, J. Y. A study on the effects of team project-led entrepreneurship education on the university student's entrepreneurship and problem-solving ability. Dankook University Master Thesis. 2017.

43. Kim, E. J. An analysis of convergence core competency affecting team creativity of industrial workers. International Journal of IT-based Management for Smart Business. 2020, 7(1), 31-40.

\section{Authors}

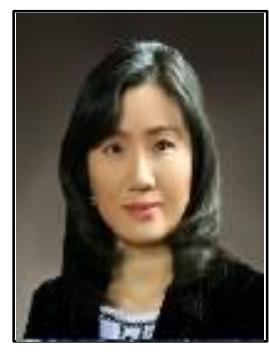

\section{Author's Name : EunJoo Kim}

Author'sprofile :EunJoo Kim, Ph.D. is a Professor of Liberal Art at Eulji University, Korea. She is a graduate of the Department of Education at Kookmin University in Korea, and the areas of research that are interested are managing the quality of education such as learners' learning experience, learning performance and education evaluation,creativity education. 